\title{
Self-reactive $T$ cells induce and perpetuate chronic relapsing arthritis
}

\author{
Jonatan Tuncel ${ }^{1 \dagger}$, Jens Holmberg ${ }^{2 \dagger}$, Sabrina Haag ${ }^{1}$, Malin Hultqvist Hopkins², Lena Wester-Rosenlöf, \\ Stefan Carlsen ${ }^{2}$, Peter Olofsson ${ }^{1}$ and Rikard Holmdahl ${ }^{1,2^{*}}$ (i)
}

\begin{abstract}
Background: $\mathrm{CD}^{+} \mathrm{T}$ cells play a central role during the early stages of rheumatoid arthritis (RA), but to which extent they are required for the perpetuation of the disease is still not fully understood. The aim of the current study was to obtain conclusive evidence that $T$ cells drive chronic relapsing arthritis.

Methods: We used the rat pristane-induced arthritis model, which accurately portrays the chronic relapsingremitting disease course of RA, to examine the contribution of T cells to chronic arthritis.

Results: Rats subjected to whole-body irradiation and injected with $C D 4^{+} T$ cells from lymph nodes of pristaneinjected donors developed chronic arthritis that lasted for more than 4 months, whereas $T$ cells from the spleen only induced acute disease. Thymectomy in combination with irradiation enhanced the severity of arthritis, suggesting that sustained lymphopenia promotes T cell-driven chronic inflammation in this model. The ability of T cells to induce chronic arthritis correlated with their expression of Th17-associated transcripts, and while depletion of T cells in rats with chronic PIA led to transient, albeit significant, reduction in disease, neutralization of IL-17 resulted in almost complete and sustained remission.
\end{abstract}

Conclusion: These findings show that, once activated, self-reactive T cells can sustain inflammatory responses for extended periods of time and suggest that such responses are promoted in the presence of IL-17.

Keywords: Chronic arthritis, Adoptive T cell transfer, PIA, Pristane, MHC class II, T cell depletion, RA

\section{Introduction}

Rheumatoid arthritis (RA) is a chronic relapsing autoimmune disease that affects approximately $0.5 \%$ of the population. Several lines of evidence indicate that $\mathrm{CD} 4^{+}$ $\alpha \beta$ T cells play a central role in the disease. First, certain alleles of MHCII, in particular, HLA-DRB1*04:01, "04: 04, "04:05, and "01:01, are strongly associated with RA [1-3], as are genes encoding molecules controlling $\mathrm{T}$ cell activation and differentiation (PTPN22, CD28 and CTLA4) [4] [5]. Second, T cells with an activated phenotype have been found to be enriched in the synovial tissue of some RA patients and although shared clonotypes have been identified across different joints [6], it remains unclear whether such $\mathrm{T}$ cell clones recognize local

\footnotetext{
* Correspondence: rikard.holmdahl@ki.se

†onatan Tuncel and Jens Holmberg contributed equally to this work.

${ }^{1}$ Division of Medical Inflammation Research, Department of Medical

Biochemistry and Biophysics, Karolinska Institutet, Stockholm, Sweden

${ }^{2}$ Section for Medical Inflammation Research, BMCI11, Lund University, Lund, Sweden
}

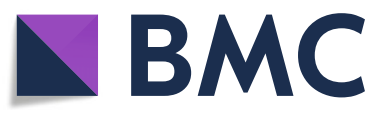

(c) The Author(s). 2020 Open Access This article is distributed under the terms of the Creative Commons Attribution 4.0 International License (http://creativecommons.org/licenses/by/4.0/), which permits unrestricted use, distribution, and reproduction in any medium, provided you give appropriate credit to the original author(s) and the source, provide a link to the Creative Commons license, and indicate if changes were made. The Creative Commons Public Domain Dedication waiver (http://creativecommons.org/publicdomain/zero/1.0/) applies to the data made available in this article, unless otherwise stated.

antigens and, if so, whether they contribute to the pathogenesis in RA. Third, therapies that intercept with CD28:CD80/86 co-stimulation, such as CTLA-4-Ig (abatacept), have been proven successful for the treatment of RA. However, CD80/86 is broadly expressed on many cell types, including osteoclasts [7], which are important for bone resorption, and although it is likely that blocking of CD80/86 suppresses $\mathrm{T}$ cell activation, the mode of action of these drugs are still incompletely understood.

Hence, while there is a broad consensus that $\mathrm{T}$ cells are important in RA, it is still unclear what role they play during the various stages of the disease [8]. Self- or crossreactive $T$ cells may contribute at an early stage of RA by providing co-stimulation to $\mathrm{B}$ cells to promote the production of autoantibodies. To provide B cell help appears to be the primary responsibility of $\mathrm{T}$ cells in many animal models of RA, such as collagen-induced arthritis (CIA) [9-12] and $\mathrm{K} / \mathrm{BxN}$ mice [13], in which transgenic $\mathrm{T}$ cells recognize the ubiquitously expressed self-antigen glucose- 
6-phosphate isomerase [14]. In both of these models, $\mathrm{T}$ cells are required for the activation of $\mathrm{B}$ cells to secrete pathogenic antibodies but are dispensable for the perpetuation of disease. In addition, aside from a few models of CIA induced by autologous collagen type II $[15,16]$, most antigen-induced models lack a chronic relapsing disease course making it impossible to address the impact of $\mathrm{T}$ cells for chronicity in these models.

In contrast, in adjuvant arthritis models, where the B cell response appears to be less critical, both the induction and perpetuation of arthritis are $\mathrm{T}$ cell-dependent. In classical adjuvant arthritis, for example, depletion of $\mathrm{CD}^{+} \mathrm{T}$ cells significantly ameliorates disease even after overt arthritis has been established. However, most of the adjuvant models are self-remitting [17], suggesting that prolonged $\mathrm{T}$ cell activation eventually leads to effector cell exhaustion and/or apoptosis. An exception is pristane-induced arthritis (PIA), which is a chronic model that, similar to RA, has a relapsing-remitting disease course [17]. Rats injected with pristane develop polyarticular arthritis with elevated levels of acute-phase reactants $[17,18]$ and IgG rheumatoid factors [19]. Since the inoculum in PIA is free from exogenous antigens, $\mathrm{T}$ cells are believed to recognize self-antigens in the context of MHCII [20, 21], and while self-antigens have been identified in PIA, e.g., collagen type XI [22] and hnRNP-A1 [23], the arthritogenic response appears to be polyclonal rather than directed towards a few major antigens [21-24].

PIA can be adoptively transferred using $\mathrm{CD}^{+} \mathrm{T}$ cells form pristane-injected rats [21]. However, whether $\mathrm{T}$ cells contribute to the perpetuation of chronic arthritis in PIA is still unclear since $\mathrm{T}$ cell-transferred rats recover from arthritis within a few weeks. In addition, while there is a strong genetic association between MHCII and the onset/severity of early PIA, there is no known association between MHCII and the development of chronic arthritis [20], suggesting that, besides the initial breach in tolerance, $\mathrm{T}$ cells might be dispensable for the perpetuation of chronic arthritis in this model.

Here, we revisited the question of whether $\mathrm{T}$ cells contribute to the perpetuation of chronicity in arthritis by examining the conditions required for optimal $\mathrm{T}$ cell transfer and by performing $\mathrm{T}$ cell ablation in rats with chronic disease.

\section{Materials and methods}

\section{PIA induction and evaluation of arthritis}

DA rats (originating from Zentralinstitut Fur Versuchstierzucht, Hannover, Germany, or, in separate experiments, Harlan Laboratories) were kept in a climate-controlled environment with 12-h light/dark cycles, housed in polystyrene cages containing wood shavings, and fed standard rodent chow and water ad libitum. Six to 10 -week-old, sex- and age-matched female and male rats were used for all arthritis experiments. The induction and monitoring of arthritis have been described previously [17]. In brief, rats were injected intradermally (i.d.) at the base of the tail with $100 \mu \mathrm{l}$ of pristane (2,6,10,14-tetramethylpentadecane) (Sigma-Aldrich). All disease assessments were performed blinded. Arthritis development was monitored in all four limbs using a previously described scoring system: 1 point (pt) was given for each swollen or red toe, $1 \mathrm{pt}$ for each swollen midcourt, digit, or knuckle, and 5 pts for a swollen ankle (max 15 pts per paw; 60 pts per rat). All experiments were approved and performed in accordance with the guidelines from the Swedish National Board for Laboratory Animals and the European Community Council Directive (86/609/EEC).

\section{T cell adoptive transfer}

Inguinal lymph nodes (iLNs) and spleen were harvested on day 14 after pristane injection. Tissues were passed through $40-\mu \mathrm{m}$ cell strainers, cells were washed in PBS and then reactivated with Concanavalin A ( $3 \mu \mathrm{g} / \mathrm{ml}$; Sigma-Aldrich) in complete DMEM medium, containing 5\% FCS, HEPES $(2.4 \mathrm{mg} / \mathrm{ml}), \beta$-mercaptoethanol $(3.9 \mu \mathrm{g} / \mathrm{ml})$, and penicillinstreptomycin $\left(10^{4} \mathrm{IU} / \mathrm{ml}\right.$ penicillin, $10 \mathrm{mg} / \mathrm{ml}$ streptomycin; Invitrogen Life Technologies). After $72 \mathrm{~h}$ of incubation at $37^{\circ} \mathrm{C}$, cells were washed and resuspended in PBS. Each recipient was transferred with $2 \times 10^{7}$ viable cells. Thymectomy was performed 3 weeks prior to transfer as previously described [25]. For whole-body irradiation, rats were exposed to a single dose of $6 \mathrm{~Gy}(600 \mathrm{rad})$ from a cesium-137 gamma-ray source, which depletes essentially all peripheral lymphocytes. Plasma concentration of cartilage oligomeric matrix protein (COMP) was determined by a competitive ELISA [26]. Levels of a1-acid glycoprotein (AGP) were measured with a soluble competitive radioimmunoassay (RIA) [27] using rat $\mathrm{a}_{1}$-acid glycoprotein.

\section{Isolation of $\mathrm{CD}^{+} \mathrm{T}$ cells for adoptive transfer}

$\mathrm{CD}^{+} \mathrm{T}$ cells were isolated from iLNs of pristane-injected rats before ConA reactivation. $\mathrm{LN}$ cells were incubated with an excessive amount $(50 \mu \mathrm{g} / \mathrm{ml})$ of anti-CD8a (OX8), anti-MQ (ED2), anti-CD45RA (OX-33), and antigranulocytes (HIS48) antibodies and were then transferred to Petri dishes $\left(5 \times 10^{6}\right.$ cells/plate), pre-coated with goat anti-mouse mAb (Jackson Immunoresearch 115-116-071; $10 \mathrm{mg} / \mathrm{ml})$. After $45 \mathrm{~min}$ of incubation at $4{ }^{\circ} \mathrm{C}$, suspended cells were counted and the purity of $\mathrm{CD}^{+} \mathrm{T}$ cells was assessed by flow cytometry (typically $>95 \%$ purity). $\mathrm{CD} 4^{+}$ $\mathrm{T}$ cells were transferred at $2 \times 10^{7}$ viable cells/recipient after ConA reactivation.

\section{Histological analysis}

Paws from recipient rats were collected and decalcified with EDTA. Cryosections were stained with hematoxylin 
and were subjected to immunohistochemical staining with the following biotinylated antibodies: anti-CD4 (OX-35), anti-MQ (ED2), and anti-Granulocytes (HIS48) (all antibodies from Pharmingen), followed by streptavidinperoxidase and visualized using the $\mathrm{DAB}$ substrate kit (DAKO, Denmark).

\section{Isolation of $\mathrm{CD}^{+}{ }^{+}$cells for mRNA expression analyses}

Inguinal LN, mesenteric LN, and spleen cells were prepared from naïve and pristane-injected (day 13 after pristane administration) rats, resuspended at $10^{7}$ cells $/ \mathrm{ml}$ in cold MACS buffer (0.5\% BSA, 2 mM EDTA in PBS) and stained with mouse antibodies against NK1.1 (10/78), $\gamma /$ STCR (V65), CD45RA (OX33), and CD8a (OX8) for 10 min at $4{ }^{\circ} \mathrm{C}$ (all antibodies were purchased from Pharmingen). After wash, cells were resuspended in $1 \mathrm{ml}$ of MACS buffer containing $50 \mu \mathrm{l}$ of Dynabeads Pan Mouse IgG (DYLAN, Oslo, Norway), incubated for $45 \mathrm{~min}$ (rotating) at $4{ }^{\circ} \mathrm{C}$ and then washed again. NK cells, NK T cells, B cells, $\gamma / \delta \mathrm{T}$ cells, and $\mathrm{CD} 8^{+}$cells were removed by magnetic depletion. Non-depleted cells were washed once, resuspended in $80 \mu \mathrm{l}$ MACS buffer, incubated for $15 \mathrm{~min}$ with $20 \mu \mathrm{l}$ CD6-coated microbeads (Miltenyi Biotec, GTF, Goteborg, Sweden) and labeled cells were then positively selected on MS-columns (Miltenyi Biotec). Purity was assessed by flow cytometry (Fig. 3b).

\section{RNA extraction and expression analyses}

$\mathrm{CD} 4^{+} \mathrm{T}$ cells were resuspended in $300 \mu \mathrm{l}$ of RLT buffer (QIAGEN Nordic, Ballerup, Denmark), containing $10 \mu \mathrm{l} / \mathrm{ml}$ $\beta$-mercaptoethanol. Automated RNA isolation was performed on a QIACube robot using the RNeasy extraction kit (Qiagen) with on-column DNase I digestion (Qiagen). RNA samples were diluted to $10 \mathrm{ng} / \mathrm{ml}$ in DEPC-treated water (Ambion). Complementary DNA (cDNA) was synthesized using the High Capacity cDNA Reverse Transcription Kit (Applied Biosystems, Foster City, CA, USA). Primers (Additional file 1: Table S1) were designed in Primer-BLAST (ncbi.nlm.nih.gov/tools/primer-blast/index. cgi) or obtained from the RTPrimerDB (medgen.ugent.be/ rtprimerdb). SYBR-Green PCR master mix (Applied Biosystems, Foster City, CA, USA) was used for all PCRs according to the manufacture's recommendation. Expression analyses were performed on an ABI Prism 7900 HT (Applied Biosystems). Specificity and efficiency of primers were validated using the absolute quantification method. Expression of targets was normalized to the expression (geometric mean) of three reference genes (Arbp, Act, and Gusb).

\section{Antibodies and immunosuppressive reagents}

Anti-mouse IL-17A antibody (clone 17F3; mouse IgG1) and isotype control antibody (clone MOPC-21) were obtained from Bio X Cell (West Lebanon, NH, USA). Crossreactivity to rat IL-17 has been evaluated previously [24].
Anti-rat $\alpha \beta T C R$ antibodies (clone R73) were produced from hybridoma. All antibodies were administrated i.v. in $0.2 \mathrm{ml}$ sterile PBS $(1 \mathrm{mg} / \mathrm{ml})$ at various time-points after pristane injection as indicated in the respective figure. Etanercept (Enbrel; Immunex, Thousand Oaks, CA, USA) was administrated i.v. $(0.2 \mathrm{ml}, 6 \mathrm{mg} / \mathrm{ml})$, methotrexate (Sandoz, Denmark) was administrated i.p. at $0.05 \mathrm{mg} / \mathrm{kg}$, and Phytol (3,7,11,15-tetramethyl-2-hexadecene-1-ol) was administrated s.c. (200 $\mu \mathrm{l}$ per rat).

\section{Flow cytometry}

Blood was collected in heparinized tubes and titers of leukocytes determined on a Sysmex KX-21N cell counter. Duplicate samples of whole blood were stained with the following fluorochrome-conjugated monoclonal antibodies: anti-CD3 (1F4), anti-CD4 (OX35), anti-granulocytes (His48), and anti-CD8 (OX8). For analyses of IFNY and IL17-producing $\mathrm{T}$ cells after treatment with anti-IL-17-neutralizing antibodies, $10^{6}$ splenocytes were resuspended in $100 \mu$ complete DMEM medium (described above) without ConA and transferred to 96-well u-bottom plates. The cells were mixed with an equal volume of the same medium containing $10 \mathrm{ng} / \mathrm{mL}$ Phorbol 12-Myristate 13-Acetate (PMA), $0.6 \mu \mathrm{g} / \mathrm{mL}$ ionomycin, and $10 \mu \mathrm{g} / \mathrm{mL}$ Brefeldin A (all from Sigma-Aldrich) and incubated for $4 \mathrm{~h}$ at $37^{\circ} \mathrm{C}$ in a $5 \% \mathrm{CO} 2$ atmosphere. PMA-stimulated cells were washed in cold EDTA-FACS buffer, stained with antibodies (described above) and then fixed and permeabilized in Cytofix/Cytoperm (BD Biosciences) for $30 \mathrm{~min}$ at RT. Cells were then stained intracellularly with antibodies against IL-17 (IC421P, purchased from R\&D Systems) and IFNY (DB-1, BD Pharming). Fluorescence-minus-one (FMO) controls were used in all panels. Dead cells were excluded from the analysis using LIVE/DEAD violet (Invitrogen, Carlsbad, CA, USA). Acquisition was made on a Becton Dickinson SORP BD LSRII Analytic Flow Cytometer and the data was analyzed with FlowJo (Tree Star Inc., Ashland, OR, USA).

\section{Statistics}

Comparisons of incidence were evaluated by Fischer's exact test. Clinical scores and quantitative PCR were analyzed using the Mann-Whitney $U$ test or KruskalWallis test with a Dunn's post-test (for quantitative PCR analyses). All analyses were performed using Graphpad Prism software (La Jolla, CA, USA). In all experiments, a $P$ value of less than 0.05 was considered significant.

\section{Results}

$\mathrm{CD}^{+} \mathrm{T}$ cells from lymph nodes, but not spleen, transfer chronic arthritis

In contrast to the high incidence of chronic arthritis in rats injected with pristane [17], the disease induced by the adoptive transfer of spleen-derived $T$ cells from pristaneinjected rats is acute and resolves spontaneously after $4-5$ 
weeks [21]. Given that lymph from the hind legs preferentially enters the inguinal lymph nodes (in addition to the popliteal lymph nodes) [28], we set out to examine whether inguinal lymph node (hereafter referred to as $\mathrm{LN}$ )-derived $\mathrm{T}$ cells would be more arthritogenic than $\mathrm{T}$ cells derived from the spleen. Transfer of in vitro-reactivated $\mathrm{T}$ cells from pristane-injected donors into syngeneic, irradiated recipients revealed no difference in the arthritogenic potency between $\mathrm{LN}$ - and spleen-derived $\mathrm{T}$ cells during the first 4-5 weeks after transfer (Fig. 1a). However, following an almost complete remission, the arthritis relapsed in rats transferred with LN-derived, but not spleenderived, T cells (Fig. 1a, b), and the histological examination at the end of the experiment (day 124) demonstrated that several, albeit not all, of the rats transferred with LNderived $\mathrm{T}$ cells had joints with severe pannus formation (Fig. 1c). In addition to the clinical and histopathological manifestations, serum from rats that had received LNderived $\mathrm{T}$ cells had elevated levels of cartilage oligomeric matrix protein (COMP) at day 124 post-transfer, indicating an active and ongoing cartilage degradation, as well as alpha-1-acid glycoprotein (AGP), an acute-phase protein whose levels are highly correlated with that of clinical arthritis in PIA [17, 18, 20] (Fig. 1d). Although the in vitro-reactivated LN cells consisted of both $\mathrm{CD} 4^{+}$and $\mathrm{CD} 8^{+} \mathrm{T}$ cells, only MHCII-restricted $\mathrm{CD} 4^{+} \mathrm{T}$ cells have been shown to be arthritogenic in PIA [20,21], and, similar to bulk T cells, purified $\mathrm{CD}^{+} \mathrm{T}$ cells induced chronic arthritis when transferred into irradiated recipients (Fig. 1e).

Taken together, LN-derived, but not spleen-derived, $\mathrm{CD}^{+} \mathrm{T}$ cells were able to induce chronic relapsing arthritis upon transfer into irradiated rats. The chronic disease lasted for at least 4 months and was accompanied by elevated serum levels of cartilage and acute-phase proteins.

\section{Impact of host-derived T cells on acute and chronic arthritis}

$\mathrm{T}$ cells from LNs of pristane-injected rats were able to induce chronic arthritis. However, the arthritis was notably mild compared to PIA, in particular in its chronic phase, suggesting that, over time, donor $\mathrm{T}$ cells lost most of their arthritogenic potency. Such gradual loss of arthritogenicity could be due to $\mathrm{T}$ cell exhaustion or arise from suppression imposed by de novo generation of host $\mathrm{T}$ cells $[29,30]$.

Although irradiation alone is sufficient to deplete the vast majority of circulating mature $\mathrm{T}$ cells (data not shown), by $40-50$ days, most peripheral $\mathrm{T}$ cells would have returned to their normal levels [31]. To assess whether the reappearance of host-derived $\mathrm{T}$ cells impacted the development and progression of arthritis, we repeated the experiment but thymectomized the recipients prior to irradiation and cell transfer. Compared with only irradiation or thymectomy, the combination of irradiation/thymectomy increased the severity of acute ( $<40$ days after transfer) and chronic ( $>40$ days after transfer) arthritis (Fig. 2a, left panel). In addition, serum from irradiated and thymectomized rats demonstrated elevated levels of AGP compared with serum from rats only irradiated or only thymectomized (Fig. 2a, right panel). In addition, the immunohistological examination of hind paws on day 65 after transfer revealed that irradiation in combination with thymectomy increased the infiltration of $\mathrm{CD}^{+}$cells and neutrophils in the synovium, whereas the presence of macrophages was similar between the groups (Fig. 2b). Thus, the return of hostderived $\mathrm{T}$ cells appeared to curtail the progression of chronic arthritis in $\mathrm{T}$ cell-transferred rats.

PIA is a valuable model for studying how antiinflammatory and immune-modulating drugs impact chronic inflammation [17]. The establishment of a chronic arthritis transfer model provided an opportunity to assess the potency of conventional RA therapy in an adjuvantfree environment. We therefore set out to test two standard-of-care therapies, etanercept (anti-TNF) and MTX, and a novel drug, phytol, a reactive oxygen speciesinducer with immune-modulating functions, that is highly potent in PIA [32], in rats with chronic transferred arthritis. Compared with vehicle (PBS) alone, all of these drugs were able to suppress the progression of arthritis in irradiated/thymectomized rats when injected on day 65 post $\mathrm{T}$ cell transfer (Fig. 2c).

Together, these findings suggest that de novo-generated host-derived $\mathrm{T}$ cells acted to suppress the arthritogenic potency of donor $\mathrm{T}$ cells, thereby limiting the development of chronic arthritis. T cell exhaustion did not seem to be causing the diminished arthritogenicity. In addition, these results show that $\mathrm{T}$ cell transfer of chronic arthritis may provide a useful model for understanding the mechanisms of immune-modulating drugs in chronic inflammation.

\section{$\mathrm{CD}^{+} \mathrm{T}$ cells in draining LNs express high levels of cytokines associated with arthritis progression}

Based on our previously published data showing that IFN$\gamma$-producing Th1 cells are critical for the early inflammatory response in PIA while IL-17 are more important for the perpetuation of disease [24], we set out to explore the expression of various cytokines and transcription factors in $\mathrm{CD}^{+} \mathrm{T}$ cells from $\mathrm{LN}$ and spleen. On day 13 after pristane injection, mRNA expression of $\mathrm{Ill}$ and the Th17-associated cytokine, Il22, was approximately 60-80fold higher in $\mathrm{CD}^{+} \mathrm{T}$ cells from inguinal than mesenteric LNs (Fig. 3a), which drains the intestine but not the joints, and whose $\mathrm{T}$ cells do not transfer arthritis (Fig. 3b). Furthermore, the expression of $I l 17$ and $I l 22$ was higher in inguinal $\mathrm{LN}$ - than spleen-derived $\mathrm{CD}^{+} \mathrm{T}$ cells from pristane-injected rats, although both transcripts were more highly expressed in spleen-derived $\mathrm{CD} 4^{+} \mathrm{T}$ cells of 


\section{A}
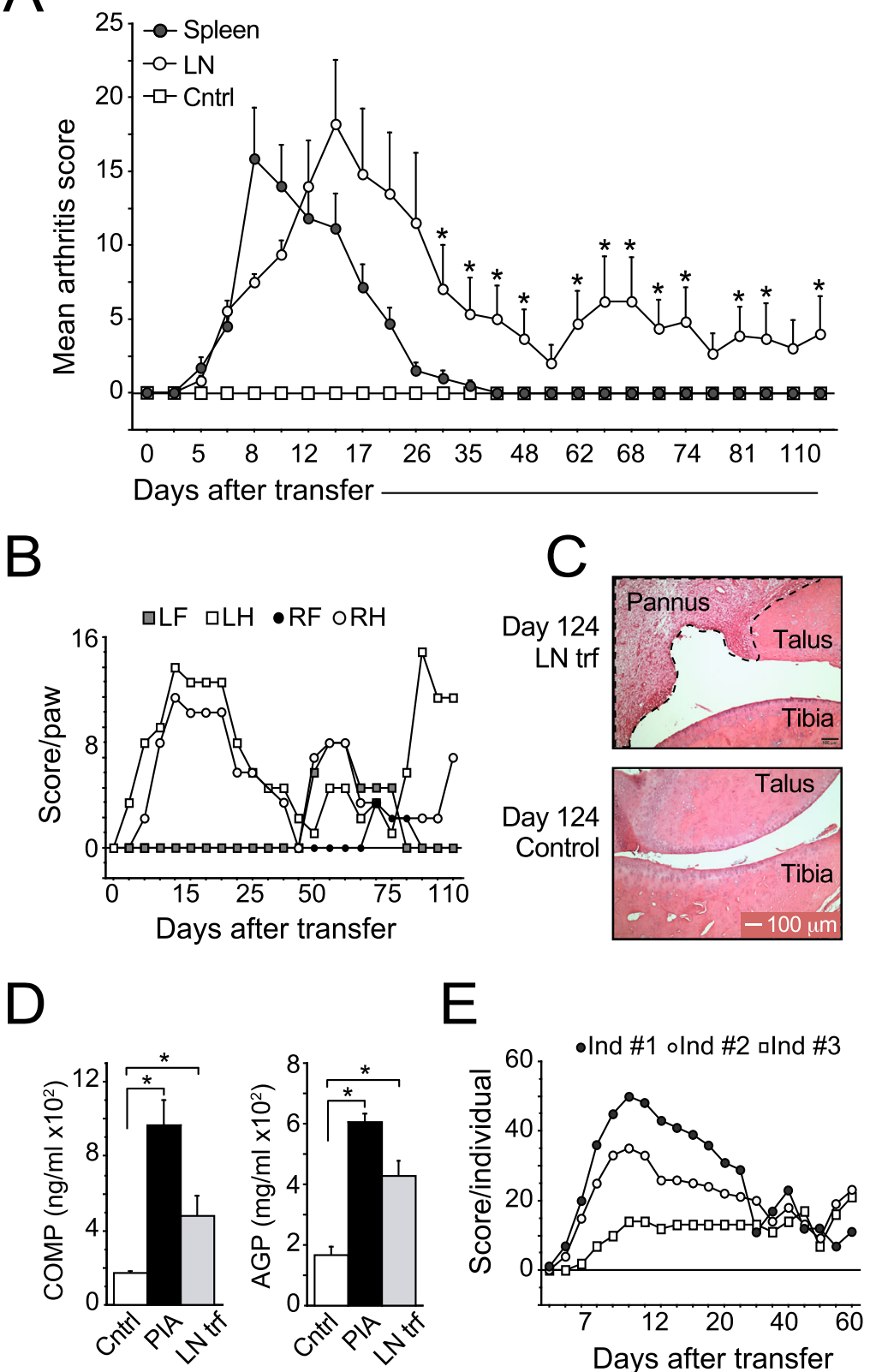

Fig. 1 Joint-draining lymph node-derived $\mathrm{CD}^{+} \mathrm{T}$ cells from pristane-injected rats induce chronic arthritis. a Arthritis development in irradiated rats transferred with $2 \times 10^{7}$ in vitro-re-stimulated cells from the LN or spleen of pristane-injected donors (14 days after pristane injection). Control rats were transferred with an equal number of non-re-stimulated $L N$ cells. $n=4$ rats/group. $\mathbf{b}$ Chronic relapses of arthritis in individual paws of a representative recipient transferred with re-

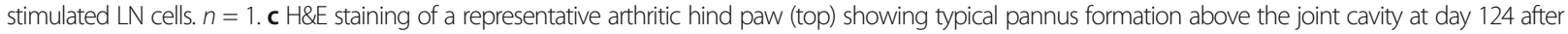
injection of re-stimulated cells from LNs of pristane-injected donors. Bottom image shows a corresponding section from a rat transferred with non-re-

stimulated cells. $\mathbf{d}$ Serum levels of COMP and AGP on day 124 post-transfer. Control, rats transferred with non-re-stimulated LN cells; PIA, rats with chronic PIA (non-transferred). $n=4-6 /$ group. e Arthritis development in irradiated rats transferred with $2 \times 10^{7}$ in vitro-re-stimulated $\mathrm{CD}^{+} \mathrm{T}$ cells. $n=3$. Data show mean values $\pm S D$. Statistical analyses using the Mann-Whitney $U$ test; ${ }^{*}<0.05$, ${ }^{* *}<0.01$. $R H$, right hind paw; $L H$, left hind paw; RF, right front paw; $L F$, left front paw

pristane-injected compared with naive rats (Fig. 3a). In contrast, the expression of Ifng (Fig. 3a) was relatively similar between inguinal $\mathrm{LN}$ - and spleen-derived $\mathrm{CD} 4^{+} \mathrm{T}$ cells after pristane injection, and neither Il4 (Fig. 3a) nor any of the transcription factors analyzed, Stat1, Stat3, Stat4, Gata3, or Tbet (Fig. 3c), showed any expressional differences that correlated with the enhanced arthritogenic potency of $\mathrm{T}$ cells from inguinal LNs.

In brief, $\mathrm{CD}^{+} \mathrm{T}$ cells from inguinal LNs of pristaneinjected rats expressed high levels of Th17-associated transcripts, which could be important for the perpetuation of chronic PIA. 


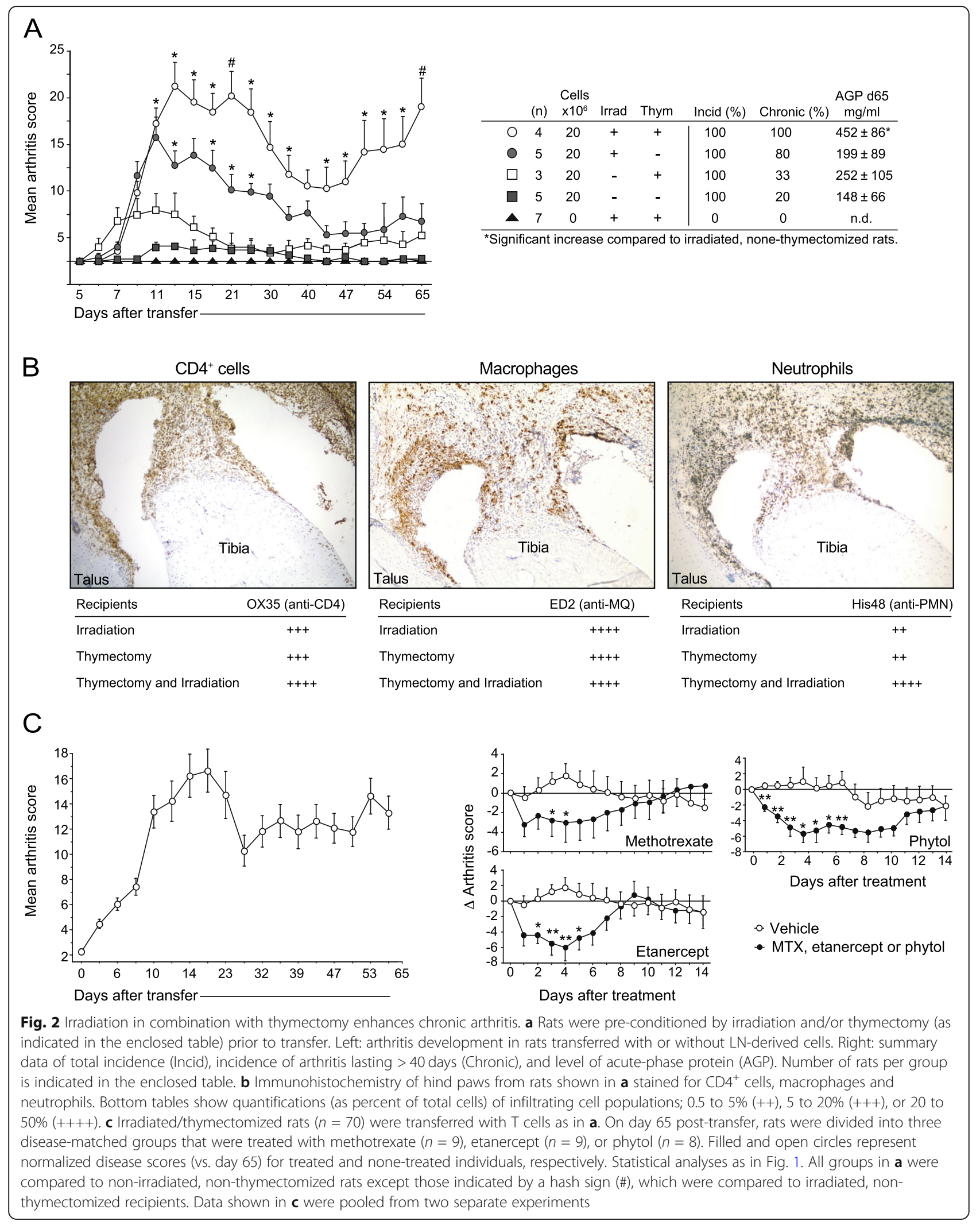




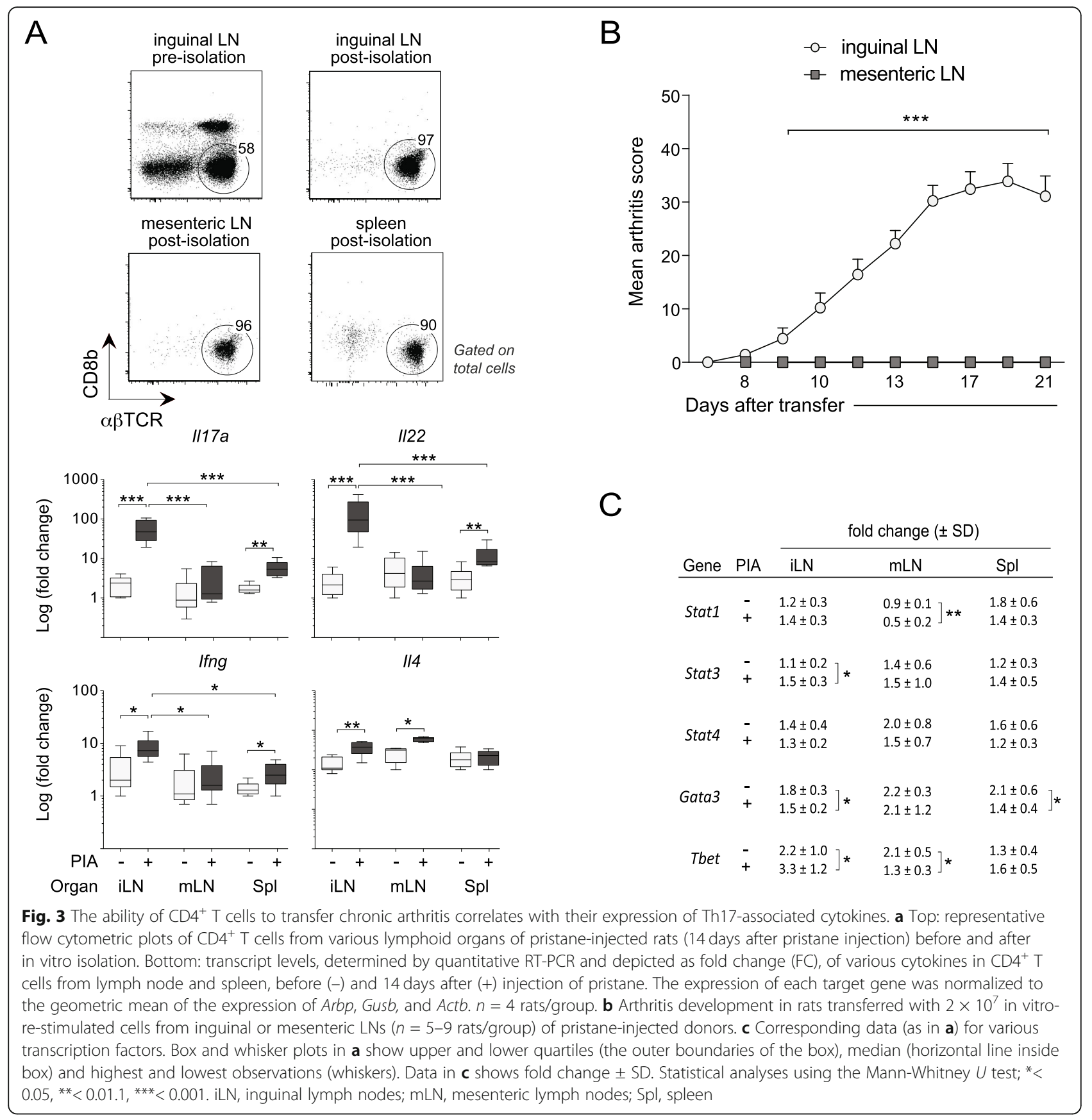

Progression of chronic PIA is T cell- and IL-17-dependent Given that $\mathrm{CD}^{+} \mathrm{T}$ cells from LNs of pristane-injected rats were able to induce and sustain arthritis in lymphopenic recipients for well over 100 days, we decided to revisit the question of whether $\mathrm{T}$ cells were critical for the perpetuation of chronic arthritis in PIA. A cohort of rats with early-stage chronic arthritis was treated with an anti- $\alpha \beta \mathrm{TCR} \mathrm{mAb}$, or an isotype-matched control mAb, on day 67, 76, and 82 after pristane injection. Within days after the first $\mathrm{mAb}$ injection, anti- $\alpha \beta \mathrm{TCR} \mathrm{mAb}-$ treated rats went into remission, which lasted for about
3-4 weeks (Fig. 4a). Flow cytometry analyses of PBMCs on day 102 after pristane injection revealed that rats treated with anti- $\alpha \beta$ TCR $\mathrm{mAb}$ had significantly lower titers of total $\mathrm{CD}^{+}$leukocytes and $\mathrm{CD}^{+}{ }^{+} \mathrm{T}$ cells compared with rats treated with an isotype-matched control mAb (Fig. 4b). Moreover, these $\mathrm{T}$ cell titers correlated with the severity of arthritis, suggesting that the arthritis remission was indeed a direct consequence of $\mathrm{T}$ cell depletion.

$\mathrm{T}$ cells from inguinal LNs expressed higher levels of Il17 than $\mathrm{T}$ cells from the spleen (Fig. 3a). To probe 


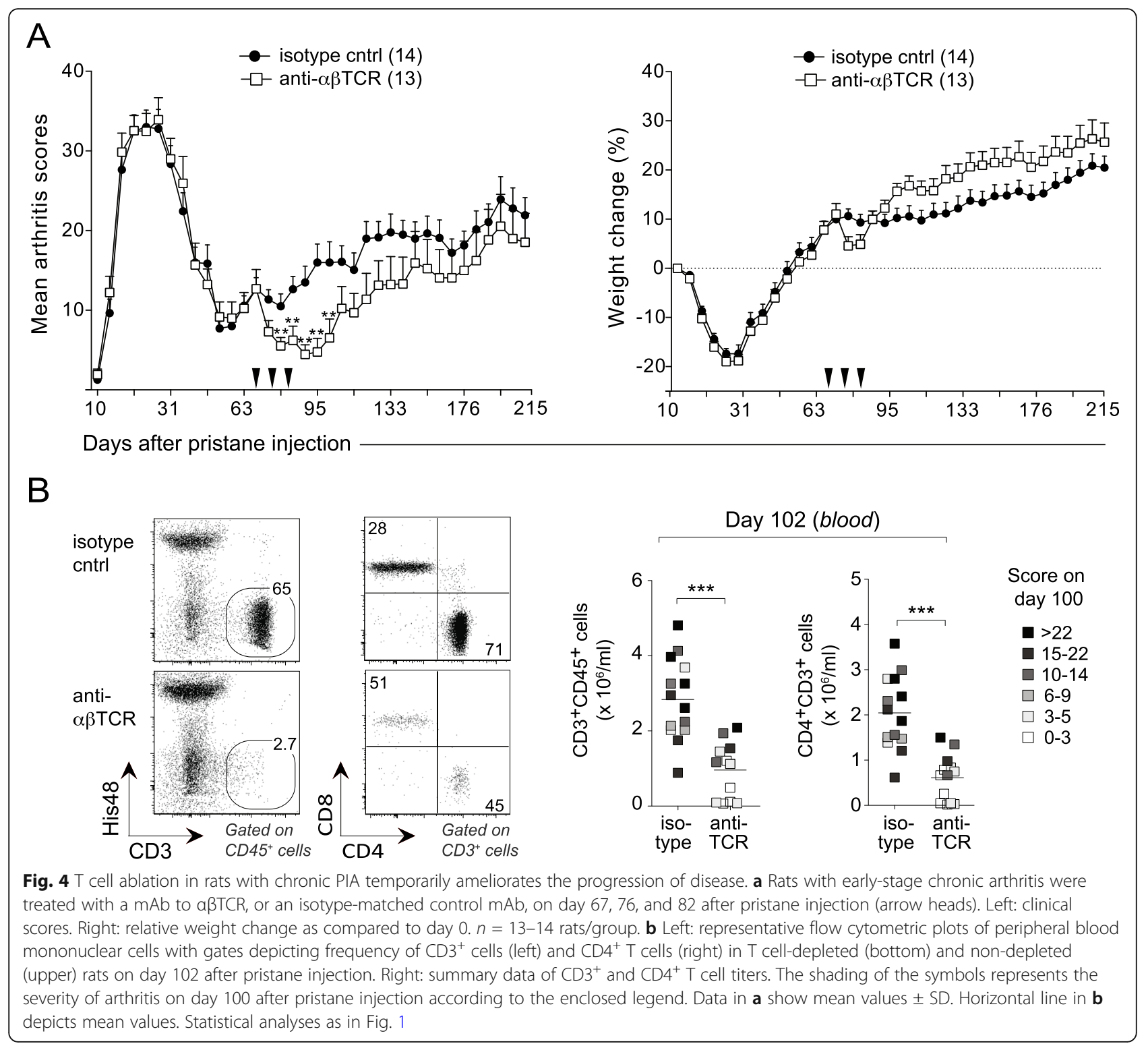

whether the production of IL-17 was associated with the development of chronic PIA, a third set of rats were treated with anti-IL-17 mAb on day 67, 76, and 82 after pristane injection. The anti-IL-17-treated rats went into remission shortly after $\mathrm{Ab}$ injection but, in contrast to rats treated with anti- $\alpha \beta T C R$ mAbs, remained in remission or had only a few relapses for the entire duration of the experiment (> 200 days) (Fig. 5a, b). Flow cytometry analyses on day 102 after pristane injection showed that rats treated with anti-IL-17 mAb had significantly reduced levels of neutrophils in the blood compared with controls (Fig. 5c), while there was no difference in the proportion of IL-17 or IFN- $\gamma$-producing CD4 $4^{+} \mathrm{T}$ cells in the spleen at the end of the experiment (day 226) (Fig. 5d).

Taken together, depletion of $\mathrm{T}$ cells resulted in a rapid, albeit transient, amelioration of chronic arthritis, suggesting that $\mathrm{T}$ cells are important for the perpetuation of chronic PIA. Compared with $\mathrm{T}$ cell depletion, the impact of neutralizing IL-17 on chronic arthritis was more potent and long-lasting.

\section{Discussion}

The question of whether and how $\mathrm{T}$ cells are actively participating in the chronic inflammatory response in RA is debated. Several studies have shown that RA synovial tissue is enriched in activated T cells [33-35], but whether those $\mathrm{T}$ cells contribute to sustaining the inflammation is unclear. Moreover, in many rodent models of RA, T cells are required for the induction but not the perpetuation of disease [9-13]. Here, we demonstrate that transfer of $T$ cells from joint-draining LNs of pristane-injected rats into lymphopenic recipients induces a type of arthritis that 
A $\quad$ - isotype cntrl (14)

-O- anti-IL-17 (13)

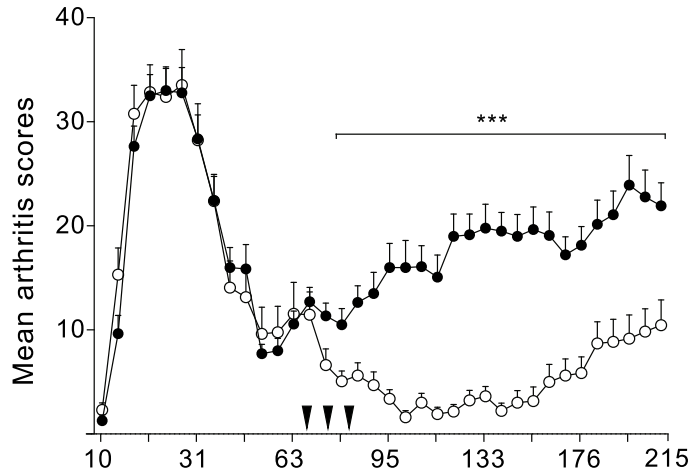

Days after pristane injection
- isotype cntrl (14)

-O- anti-IL-17 (13)

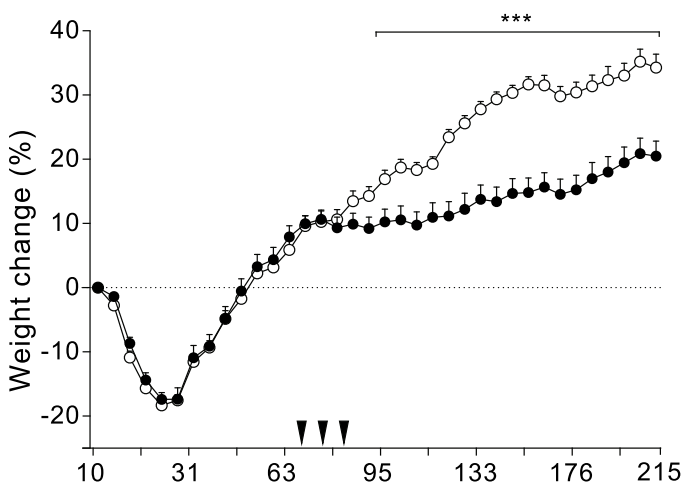

B

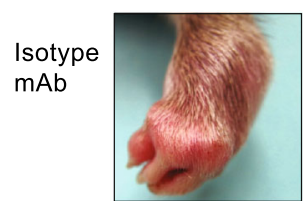

$\alpha \mathrm{IL}-17$
$\mathrm{mAb}$

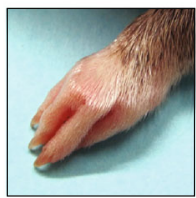

$D$
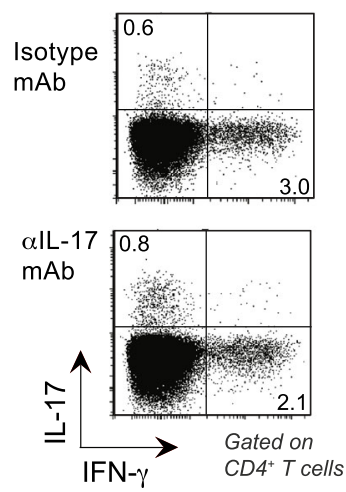

C
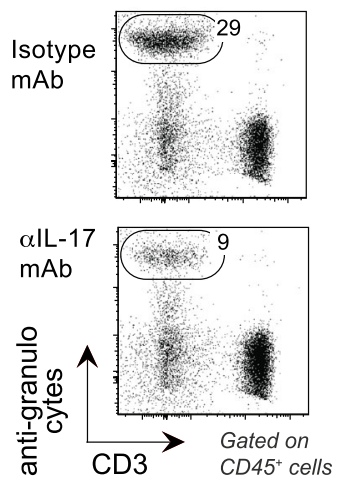

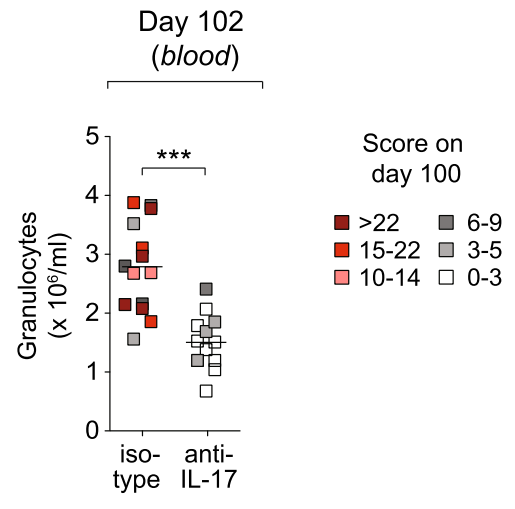

Day 102

day 100

$15-22 \square 3-5$

$10-14 \square 0-3$

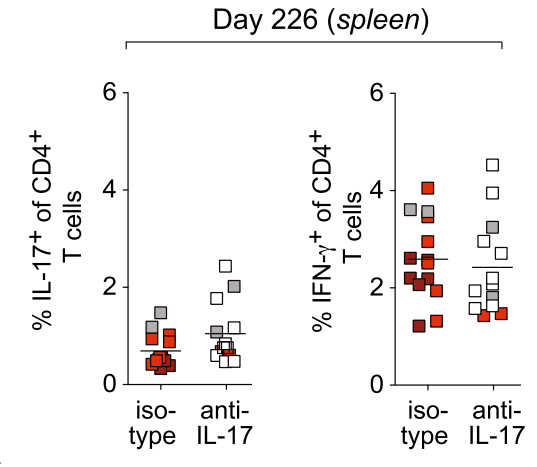

Fig. 5 Neutralization of IL-17 efficiently blocks the progression of chronic disease in PIA. a Rats, which were part of the same cohort as those shown in Fig. 4, were treated with a mAb to IL-17, or an isotype-matched control mAb, on day 67, 76, and 82 after pristane injection (arrow heads). Left: clinical scores. Right: relative weight change as compared to day $0 . n=13-14$ rats/group. b Representative images of front paws of rats injected with pristane (day 102 after injection) and treated with either IL-17 depleting or isotype control antibodies. c Left: representative flow cytometric plots of peripheral blood mononuclear cells with gates depicting frequency of granulocytes in IL-17-depleted (bottom) and nondepleted (upper) rats on day 102 after pristane injection. Right: summary data of granulocyte titers. $\mathbf{d}$ Representative flow cytometric plots and summary data for the percentage of $\mathrm{IL}-17^{+}$and IFNy ${ }^{+} \mathrm{CD} 4^{+} \mathrm{T}$ cells on day 226 in the spleen. The colors of the symbols in $\mathbf{c}$ and $\mathbf{d}$ represent the severity of arthritis on day 100 after pristane injection according to the enclosed legends. Data in a show mean values \pm SD. Horizontal line in c and $\mathbf{d}$ depicts mean values. Statistical analyses as in Fig. 1 
essentially phenocopies the relapsing-remitting disease course of PIA. In addition, rats with late-stage chronic PIA temporarily recovered from arthritis when treated with $\mathrm{T}$ cell-depleting antibodies. Taken together, these findings suggest that $\mathrm{T}$ cells play an important role during the chronic stage of PIA.

A number of pre-conditioning regimens were required to enhance the efficiency of the adoptive $\mathrm{T}$ cell transfer. First, pre-conditioning of recipient rats by gamma radiation and thymectomy was important for the induction of chronic arthritis. While lymphoablation through irradiation will allow donor $\mathrm{T}$ cells to expand in the host, over time, such expansion, known as lymphopeniainduced proliferation (LIP), is dampened as new T cells egress from the thymus. Regulatory $\mathrm{T}$ (Treg) cells are particularly important to suppress LIP [36]. Treg cells are also known to undergo extensive proliferation under semi-lymphopenic conditions as long as the levels of IL2 are sufficient $[37,38]$, which may explain why they are typically overrepresented in the peripheral $\mathrm{T}$ cells pool after lymphodepletion [39]. Such expansion of Treg cells under lymphopenic conditions induces a state of generalized immune suppression, which may explain why $\mathrm{T}$ cells from pristane-injected donors failed to induce chronic disease in irradiated, non-thymectomized rats.

Second, spleen-derived T cells turned out to be surprisingly inefficient inducers of chronic arthritis. Quantitative PCR analyses revealed that $\mathrm{CD} 4^{+} \mathrm{T}$ cells from the spleen of pristane-injected rats expressed lower levels of Th17associated cytokines than $\mathrm{CD} 4^{+} \mathrm{T}$ cells from dLNs, suggesting a difference in the proportion of Th17 cells (or in the relative expression of $I l 17$ and $I l 22$ transcripts) between the two organs. Therefore, given the importance of IL-17 in PIA [24], it is possible that spleen-, in contrast to LN-, derived $\mathrm{T}$ cells lack the properties necessary to sustain a chronic immune response. Moreover, as shown by Catron et al., tissue-draining LNs continue to be seeded by antigen-specific late-arriving $\mathrm{T}$ cells, which are enriched in central-memory cells, in the first several weeks after the primary immune response is over [40]. Such late-arriving T cells may be particularly apt in inducing chronic arthritis because of their enhanced regeneration capacity and ability to produce differentiated $\mathrm{T}$ cells with effector potential [41]. In this context, it is interesting to note that only $\mathrm{T}$ cells from joint-draining LNs were able to transfer chronic arthritis but it remains a challenge to identify the specificity and phenotype of this small subset of pathogenic cells.

The transfer experiments, discussed above, suggest that $\mathrm{T}$ cells contribute to the pathogenesis in chronic PIA, a notion that was further supported by $\mathrm{T}$ cell ablation in pristane-injected rats with chronic disease, which showed significant, albeit transient, recovery from arthritis. Although $\mathrm{T}$ cell depletion had limited effectiveness on disease, in particular in comparison to IL-17 neutralization, the correlation between clinical scores and $\mathrm{T}$ cell numbers strongly support a causative relationship between $\mathrm{T}$ cells and disease progression. It is worth noting that, in clinical studies, $\mathrm{T}$ cell-depleting strategies have generally proven to be ineffective, too, which is likely due to a combination of immunogenicity and that an extremely small number of self-reactive $\mathrm{CD} 4^{+} \mathrm{T}$ cells is sufficient to sustain the inflammation in RA [42]. To identify the specificity of those $\mathrm{CD}^{+} \mathrm{T}$ cells has proven to be a challenging task in humans. Here, PIA might offer a suitable surrogate system that is free from exogenous antigens that otherwise could disguise the true specificity of self-reactive $\mathrm{T}$ cells. As noted above, the fact that various lymphoid tissues in this model harbor $\mathrm{CD}_{4}^{+} \mathrm{T}$ cells with different potential to induce chronic arthritis might be harnessed to identify the specificity of importance for self-reactive $\mathrm{T}$ cells.

\section{Conclusions}

In summary, we have demonstrated that $\mathrm{LN}$-derived $\mathrm{T}$ cells from pristane-injected rats are able to induce chronic relapsing arthritis in lymphopenic, thymectomized recipients. The ability to transfer chronic disease correlated with a high production of Th17-associated cytokines, and neutralization of IL-17 in rats with chronic PIA efficiently dampened the progression of PIA. It is important to keep in mind that RA is not a singular disease with a defined disease etiology. Through the work in animal models, it has become clear that chronic inflammation may arise for various reasons, some involving $\mathrm{T}$ cells and others not, and it is likely that a similar level of heterogeneity exists in human RA.

\section{Supplementary information}

Supplementary information accompanies this paper at https://doi.org/10. 1186/s13075-020-2104-7.

Additional file 1: Table S1. Primers for expression analyses.

\begin{abstract}
Abbreviations
AGP: a1-acid glycoprotein; COMP: Cartilage oligomeric matrix protein; i.d.: Intradermal; LL-17: Interleukin 17; LN: Lymph node; MTX: Methotrexate; PIA: Pristane-induced arthritis; RA: Rheumatoid arthritis
\end{abstract}

\section{Acknowledgements}

We thank Carlos and Kristina Palestro, Isabell Bohlin, Sandy Liedholm, and Rebecka Ljungqvist for taking care of the animals and Margareta Svejme for preparing the histology slides.

\section{Authors' contributions}

JT designed the research, performed and analyzed the experiments, and wrote and revised the manuscript. JH contributed to experimental T cell transfer data. SH contributed to experimental data and assisted in writing the paper. $\mathrm{MH}, \mathrm{LR}, \mathrm{SC}$, and $\mathrm{PO}$ contributed to experimental data and helped in revising the manuscript. $\mathrm{RH}$ designed the research, analyzed data, revised the manuscript, and supervised the project. All authors approved the final manuscript. $\mathrm{RH}$ takes the overall responsibility. 


\section{Funding}

The research leading to these results has received funding from the Swedish Rheumatism Association, the Swedish Medical Research Council, and the Swedish Foundation for Strategic Research. JT was supported by the Swedish Research Council grant 2015-00364. None of the funding bodies had any influence on the design of the study and collection, analysis, and interpretation of data and in writing the manuscript. Open access funding provided by Karolinska Institute.

\section{Availability of data and materials}

All data and material presented are accessible upon request to the corresponding author.

\section{Ethics approval and consent to participate}

No human material was used. All animal experiments were approved and performed in accordance with the guidelines from the Swedish National Board for Laboratory Animals and the European Community Council Directive (86/609/EEC).

\section{Consent for publication}

\author{
Not applicable
}

\section{Competing interests}

$\mathrm{PO}, \mathrm{MH}$, and $\mathrm{RH}$ have financial interest in the company Redoxis $\mathrm{AB}$ that provides research service in the area of preclinical models including the model described in this article. The other authors declare that they have no competing interests.

\section{Received: 12 September 2019 Accepted: 13 January 2020}

Published online: 28 April 2020

\section{References}

1. Kim K, Bang S-Y, Lee H-S, Cho S-K, Choi C-B, Sung Y-K, et al. High-density genotyping of immune loci in Koreans and Europeans identifies eight new rheumatoid arthritis risk loci. Ann Rheum Dis. 2015;74:e13.

2. Okada Y, Terao C, Ikari K, Kochi Y, Ohmura K, Suzuki A, et al. Meta-analysis identifies nine new loci associated with rheumatoid arthritis in the Japanese population. Nat Genet. 2012:44:511-6.

3. Stahl EA, Raychaudhuri S, Remmers EF, Xie G, Eyre S, Thomson BP, et al. Genome-wide association study meta-analysis identifies seven new rheumatoid arthritis risk loci. Nat Genet. 2010;42:508-14.

4. Plenge RM, Padyukov L, Remmers EF, Purcell S, Lee AT, Karlson EW, et al. Replication of putative candidate-gene associations with rheumatoid arthritis in >4,000 samples from North America and Sweden: association of susceptibility with PTPN22, CTLA4, and PADI4. Am J Hum Genet. 2005;77: 1044-60.

5. The RACl. consortium, the GARNET consortium, Okada Y, Wu D, Trynka G, Raj T, et al. Genetics of rheumatoid arthritis contributes to biology and drug discovery. Nature. 2013;506:376-81.

6. Cantaert T, Brouard S, Thurlings RM, Pallier A, Salinas GF, Braud C, et al. Alterations of the synovial $T$ cell repertoire in anti-citrullinated protein antibody-positive rheumatoid arthritis. Arthritis Rheum. 2009;60:1944-56.

7. Axmann R, Herman S, Zaiss M, Franz S, Polzer K, Zwerina J, et al. CTLA-4 directly inhibits osteoclast formation. Ann Rheum Dis. 2008;67:1603-9.

8. Scherer HU, Huizinga TWJ, Krönke G, Schett G, Toes REM. The B cell response to citrullinated antigens in the development of rheumatoid arthritis. Nat Rev Rheumatol. 2018;14:157-69.

9. Svensson $L$, Jirholt J, Holmdahl R, Jansson L. B cell-deficient mice do not develop type II collagen-induced arthritis (CIA). Clin Exp Immunol. 1998;111: 521-6.

10. Bajtner E, Nandakumar KS, Engström A, Holmdahl R. Chronic development of collagen-induced arthritis is associated with arthritogenic antibodies against specific epitopes on type II collagen. Arthritis Res Ther. 2005;7: R1148-57.

11. Dahdah A, Habir K, Nandakumar KS, Saxena A, Xu B, Holmdahl R, et al. Germinal Center B Cells Are Essential for Collagen-Induced Arthritis. Arthritis Rheum. 2018:70:193-203.

12. Bäcklund J, Li C, Jansson E, Carlsén S, Merky P, Nandakumar KS, et al. C57BL/ 6 mice need MHC class II Aq to develop collagen-induced arthritis dependent on autoreactive T cells. Ann Rheum Dis. 2013;72:1225-32.
13. Kouskoff V, Korganow AS, Duchatelle V, Degott C, Benoist C, Mathis D. Organ-specific disease provoked by systemic autoimmunity. Cell. 1996;87: 811-22.

14. Matsumoto I, Staub A, Benoist C, Mathis D. Arthritis provoked by linked T and B cell recognition of a glycolytic enzyme. Science. 1999;286:1732-5.

15. Goldschmidt TJ, Holmdahl R. Anti-T cell receptor antibody treatment of rats with established autologous collagen-induced arthritis: suppression of arthritis without reduction of anti-type II collagen autoantibody levels. Eur J Immunol. 1991;21:1327-30.

16. Holmdahl R, Jansson L, Larsson E, Rubin K, Klareskog L. Homologous type II collagen induces chronic and progressive arthritis in mice. Arthritis Rheum. 1986;29:106-13.

17. Tuncel J, Haag S, Hoffmann MH, Yau ACY, Hultqvist M, Olofsson P, et al. Animal models of rheumatoid arthritis (I): pristane-induced arthritis in the rat. PLoS One. 2016;11:e0155936-e0155917 Zhou H, ed.

18. Olofsson P, Nordquist N, Vingsbo-Lundberg C, Larsson A, Falkenberg C, Pettersson $U$, et al. Genetic links between the acute-phase response and arthritis development in rats. Arthritis Rheum. 2002;46:259-68.

19. Rintisch C, Ameri J, Olofsson P, Luthman H, Holmdahl R. Positional cloning of the Igl genes controlling rheumatoid factor production and allergic bronchitis in rats. Proc Natl Acad Sci. 2008:105:14005-10.

20. Haag S, Tuncel J, Thordardottir S, Mason DE, Yau ACY, Dobritzsch D, et al. Positional identification of RT1-B (HLA-DQ) as susceptibility locus for autoimmune arthritis. J Immunol. 2015;194(6):2539-50.

21. Holmberg J, Tuncel J, Yamada H, Lu S, Olofsson P, Holmdahl R. Pristane, a non-antigenic adjuvant, induces MHC class II-restricted, arthritogenic T cells in the rat. J Immunol. 2006;176:1172-9.

22. Tuncel J, Haag S, Carlsén S, Yau ACY, Lu S, Burkhardt H, et al. Class II major histocompatibility complex-associated response to type XI collagen regulates the development of chronic arthritis in rats. Arthritis Rheum. 2012; 64:2537-47

23. Hoffmann MH, Tuncel J, Skriner K, Tohidast-Akrad M, Türk B, Pinol-Roma S, et al. The rheumatoid arthritis-associated autoantigen hnRNP-A2 (RA33) is a major stimulator of autoimmunity in rats with pristane-induced arthritis. J Immunol. 2007;179:7568-76.

24. Tuncel J, Haag S, Holmdahl R. MHC class II alleles associated with Th1 rather than Th17 type immunity drive the onset of early arthritis in a rat model of rheumatoid arthritis. Eur J Immunol. 2017;47(3):563-74.

25. Reeves JP, Reeves PA, Chin LT. Survival surgery: removal of the spleen or thymus. Curr Protoc Immunol. 2001; Chapter 1:Unit 110.

26. Saxne T, Heinegard D. Cartilage oligomeric matrix protein: a novel marker of cartilage turnover detectable in synovial fluid and blood. Br J Rheumatol. 1992;31(9):583-91.

27. Akerstrom B. Immunological analysis of alpha 1-microglobulin in different mammalian and chicken serum. alpha 1-Microglobulin is 5-8 kilodaltons larger in primates. J Biol Chem. 1985;260(8):4839-44.

28. Harrell MI, Iritani BM, Ruddell A. Lymph node mapping in the mouse. J Immunol Methods. 2008:332:170-4

29. Dummer W, Ernst B, LeRoy E, Lee D, Surh C. Autologous regulation of naive T cell homeostasis within the T cell compartment. J Immunol. 2001;166: 2460-8.

30. Crawford A, Angelosanto JM, Kao C, Doering TA, Odorizzi PM, Barnett BE, et al. Molecular and transcriptional basis of CD4+ T cell dysfunction during chronic infection. Immunity. 2014;40:289-302.

31. Bazin H, Platteau B. Lymphocyte disappearance and reappearance after a single whole-body irradiation dose of 5 Gy. Ann Inst Pasteur Immunol. 1986; 137C:313-28.

32. Hultqvist M, Olofsson P, Gelderman KA, Holmberg J, Holmdahl R. A new arthritis therapy with oxidative burst inducers. PLoS Med. 2006;3:e348 Verweij $C$, ed.

33. Duke O, Panayi GS, Janossy G, Poulter LW. An immunohistological analysis of lymphocyte subpopulations and their microenvironment in the synovial membranes of patients with rheumatoid arthritis using monoclonal antibodies. Clin Exp Immunol. 1982:49:22-30.

34. Lundy SK, Sarkar S, Tesmer LA, Fox DA. Cells of the synovium in rheumatoid arthritis. T lymphocytes. Arthritis Res Ther. 2007;9:202

35. Mclnnes IB, Leung BP, Liew FY. Cell-cell interactions in synovitis. Interactions between T lymphocytes and synovial cells. Arthritis Res. 2000;2:374-8.

36. Winstead CJ, Fraser JM, Khoruts A. Regulatory CD4+CD25+Foxp3+ T cells selectively inhibit the spontaneous form of lymphopenia-induced proliferation of naive T cells. J Immunol. 2008;180:7305-17. 
37. Almeida ARM, Zaragoza B, Freitas AA. Indexation as a novel mechanism of lymphocyte homeostasis: the number of CD4+CD25+ regulatory T cells is indexed to the number of IL-2-producing cells. J Immunol. 2006;177:192200.

38. Moxham VF, Karegli J, Phillips RE, Brown KL, Tapmeier TT, Hangartner R, et al. Homeostatic proliferation of lymphocytes results in augmented memorylike function and accelerated allograft rejection. J Immunol. 2008;180:39108.

39. Baba J, Watanabe S, Saida Y, Tanaka T, Miyabayashi T, Koshio J, et al. Depletion of radio-resistant regulatory $T$ cells enhances antitumor immunity during recovery from lymphopenia. Blood. 2012;120:2417-27.

40. Catron DM, Rusch LK, Hataye J, Itano AA, Jenkins MK. CD4 +T cells that enter the draining lymph nodes after antigen injection participate in the primary response and become central-memory cells. J Exp Med. 2006;203: 1045-54.

41. Mahnke YD, Brodie TM, Sallusto F, Roederer M, Lugli E. The who's who of Tcell differentiation: human memory T-cell subsets. Eur J Immunol. 2013;43: 2797-809.

42. Keystone E. Treatments no longer in development for rheumatoid arthritis. Ann Rheum Dis. 2002;61(Suppl 2):ii43-5.

\section{Publisher's Note}

Springer Nature remains neutral with regard to jurisdictional claims in published maps and institutional affiliations.

Ready to submit your research? Choose BMC and benefit from:

- fast, convenient online submission

- thorough peer review by experienced researchers in your field

- rapid publication on acceptance

- support for research data, including large and complex data types

- gold Open Access which fosters wider collaboration and increased citations

- maximum visibility for your research: over $100 \mathrm{M}$ website views per year

At $\mathrm{BMC}$, research is always in progress.

Learn more biomedcentral.com/submissions 